\title{
Resale of Restricted Securities under SEC Rule 144
}

When a corporation offers to sell its securities to the public, it is required by the Securities Act of 1933 [hereinafter 1933 Act] ${ }^{1}$ to file a detailed registration statement with the Securities and Exchange Commission and to deliver a prospectus to each offeree. ${ }^{2}$ The object of-registration is to provide the investing public with the information needed to make intelligent investment decisions.

Because the registration process is both time-consuming and expensive, a statutory exemption from registration for securities sold privately provides an attractive alternative to a public offering. The issuer, by selling securities privately, is able to raise funds without incurring the delay and expense of registration. Private placement is equally attractive to investors, who often purchase the securities on terms more favorable than those in a public offering.

Difficult questions arise, however, when the purchaser of privately placed securities decides to resell those securities to the public. The Commission has attempted to define the circumstances under which the public resale of unregistered, privately placed securities does not pose the dangers that the 1933 Act sought through registration to avert.

The most recent effort of the Commission to deal with this question is embodied in SEC Rule $144,{ }^{3}$ which became effective in April 1972. The rule seeks to protect the public by requiring anyone who resells privately placed securities to demonstrate compliance with several objectively-measurable conditions. Under the pre-Rule 144 administrative practice, the "intent" of the person reselling was a crucial element in the determination of whether public resale would be permitted without registration. Ascertainment of intent involved a case-by-case evaluation of a variety of facts surrounding the resale. The holder of restricted securities may now elect to have his actions

1. 15 U.S.C. $\$ \S 77(a) \cdot(a a)$ (1970) [hereinafter cited as 1933 Act, with sections as rcnumbered by Act of August 20, 1964, Pub. L. No. 88.467, $\S 12,78$ Stat. 58].

2. 1933 Act $\$ 5$.

3. SEC Rule 144, 37 Fed. Reg. 596 (1972) [hereinafter cited as Rule 144], SEG Sccurities Act Release No. 5223 (Jan. 11, 1972). Earlier versions of the rule are set out in SEC Securities Act Release No. 5186 (Sept. 10, 1971), SEC Securities Act Release No. 5087 (Sept. 15, 1969). The original proposals for a rule specifying objective standards to govern resale of restricted securities were made in SEC, DiscLosunE To INVESTOHS Appendix VI-1 at 149-247 (CCH ed. 1969) [hereinafter cited as Wirent REvonT; Wheat chaired the special committee that wrote the recommendations]. 
evaluated either under the traditional "intent" standard or the new Rule 144 standard. As a practical matter, however, Rule 144 is likely to be favored by purchasers of restricted securities, because it makes resale more certain and predictable than does the "intent" standard.

This Note will examine the probable impact of Rule 144 on private placements and will evaluate the protective value of its requirements. It will be argued that Rule 144 weakens the public protection the securities laws were intended to provide.

\section{Private Financing under the Securities Act of 1933}

The basic premise of the 1933 Act is that the offer to sell or sale of any security requires registration. ${ }^{*}$ Congress, however, specifically exempted from registration certain types of securities and transactions for which it was thought there was no practical need for registration. Two exemptions in particular concern this Note. The first is the Section 4(2) "private placement" exemption for "transactions by an issuer ... not involving a public offering." 5 This exempts a company's specific or isolated sale of its securities to a limited number of persons $^{6}$ who have access to the kind of information registration would provide. ${ }^{7}$ The provision embodies the policy judgment that the sale of an issue of securities, usually debt, ${ }^{8}$ to a small group of professional investors is not the concern of the federal government. ${ }^{\circ}$ The wealthy individuals and institutional investors who purchase such

4. H.R. Rep. No. 85, 73d Cong., 1st Sess. $15-16$ (1933); Landis, The Legislative Hislory of the Securities Act, 28 Geo. WASh. L. Rev. 29, 37 (1959).

5. 1933 Act $\$ 4(2)$.

6. The SEC has never promulgated a numerical limit to the number of permissible offerees in a private placement, SEC Securities Act Release No. 4552 (Nov. 6, 1962); SEC Securities Act Release No. 285 (Jan. 24, 1935). However, if the number of offerees is large the transaction may be held to be a public offering. Sec, e.g., SEC v. Ralston Purina Co., 346 U.S. 119 (1953); SEC v. Sunbeam Gold Mines Co., 95 F.2d 699 (9th Cir. 1938) (offering of shareholder receipts to 530 persons); Martin Yale Industries, Inc., [1971-1972 Transfer Binder] CCH FED. SEc. L. REP. $\$ 78,673$ (1972) (offer to 10 employces); The offer need not be made to investors at large, or the sale transacted on a mational exchange, to be a "public offering." Strahan v. Pedroni, 387 F.2d 730 (5th Cir. 1970). In fact, an offer to as few as twenty-five individuals may be found to be a public offering. Crowell-Collier Publishing Co., SEC Securities Act Release No. 3825 (Âug. 12, 1957). The number of permissible offerees often appears to be inversely related to the level of sophistication and access to information about the issuer. But even where the investors are concededly sophisticated, an offer to a large group may be a public offering. See Hazel Bishop, Inc., 40 S.E.C. 718 (1961) (offer to 500 sophisticated investors considered a public offering).

7. SEC v. Ralston Purina Co., 346 U.S. 119 (1953); SEC v. Continental Tobacco Co., BNA SEC. Reg. L. ReP. No. 155 at H-1 (5th Cir. 1972), rev'g 326 F. Supp. 583 (S.D. Fla. 1971).

8. In 1971, eighty-three per cent of privately placed securities were debt issues. SEC, Statistical Bulletin 18-19 (March 1972).

9. Landis, supra note 4 , at 37 . 
unregistered securities ${ }^{10}$ presumably have the economic bargaining power and sophistication to protect themselves. ${ }^{11}$

The private placement exemption would be a major loophole if the general policy of registration could be evaded by a private sale to a small number of sophisticated investors who in turn could sell the unregistered securities to the public. Thus, one requirement of a bona fide private placement is that it cannot be made to individuals who buy for resale to the public. ${ }^{12}$ If a purchaser is found to be a mere conduit ${ }^{13}$ for a wider distribution, the initial unregistered sale to persons reasonably expected to market them to the public would be one involving a public offering. ${ }^{14}$ Even though the corporate issuer does not make the ultimate sale of the unregistered securitics to the public, it may be held liable for the purchase price in an action by public purchasers of the securities. ${ }^{15}$

The second relevant exemption from registration is that in Section 4(1), for "ordinary trading transactions" between individual members of the investing public. ${ }^{16}$ If the purchaser of a private place-

10. Though precise figures are not available, the major part of unregistercd cash offerings has been private sales to institutional investors. I REPORT OF TIIE SiEcinL Study of the Securities Markets of the S.E.C., H.R. Doc. No. 95, 88th Cong, 1st Sess. 483 (1963).

11. In Value Line Fund, Inc. v. Marcus, [1964-1966 Transfer Binder] CCHI FEd, SEc. L. Rep. If 91,523 (S.D.N.Y. 1965), the court refused to permit a sale of unregistered stock to be rescinded under $\$ 12(1)$ of the 1933 Act. The plaintiff mutual fund possessed enough information to demand, and enough leverage at the bargaining table to receive, all information relevant to make a fully informed decision on whether or not to buy Hoffman stock.

Id. at 94,970. See also Orrick, Some Observations on the Administration of the Securitics Laws, 42 MinN. L. REv. 25, 33 (1957). This presumption of access to information is rebuttable. For example, in United States v. Custer Channel Wing Corp., 376 F.2d 675 (4th Cir. 1967), cert. denied, 389 U.S. 932 (1967), "businessmen of mature experience" were shown not to have access to information of the type registration would provide. Recent cases on the subject are SEC v. Continental Tobacco Co., BNA, SEc. REG. $\mathbf{L}$. REP. No. 155, at H-1 (5th Cir. 1972); Henderson v. Hayden Stone Inc. [Current] C.CH Fed. SEC. L. ReP. I 93,504 (5th Cir. 1972); Hill York Corp. v. American Int'l Franchises, 448 F.2d 680 (5th Cir. 1971); Lively v. Hershfeld, 440 F.2d 631 (10th Cir. 1971).

12. SEC v. North Am. Research \& Dev., 280 F. Supp. 106 (S.D.N.Y. 1968), aff'd in part, vacated in part on other grounds, 424 F.2d 63 (2d Cir. 1970); SEC v. Bond and Share Corp., 229 F. Supp. 88 (W.D. Okla. 1963); SEC v. Mono-Kearsage Consol. Mining Co., 167 F. Supp. 248 (D. Utah 1958); SEC Securities Act Release No. 4162 (Dec. 2, 1959).

13. Gilligan, Will \& Co. v. SEC, 267 F.2d 461 (2d Cir. 1959).

14. SEC Securities Act Release No. 4162 (Dec. 2, 1969); SEC Securities Act Rclcasc No. 3825 (Aug. 12, 1957); Ambrosia Minerals Inc., 39 S.E.C. 734 (1960); Elliott \& Co." 38 S.E.C. 381 (1958).

15. Section 12(1) of the 1933 Act provides in pertinent part:

Any person who .... offers or sells a security in violation of Section 5 . . shall be liable to the person purchasing such security from him, who may suc either at law or in equity in any court of competent jurisdiction; to recover the consideration paid for such security with interest thereon, upon the tender of such sccurity, or for damages if he no longer owns the security.

See, e.g., Katz v. Amos Treat \&. Co., 411 F.2d 1046 (2d Cir. 1971).

16. "The provisions of Section 5 shall not apply to transactions by any person other than an insurer, underwriter, or dealer ...." 1933 Act $\$ 4(1)$. See H.R. REP. No. 85, 73d Cong., 1st Sess. 15-16 (1933). 
ment is to sell those securities publicly, he must meet the terms of this section. So far as is here relevant, the transaction may not involve an underwriter. ${ }^{17}$ A private placement purchaser is an underwriter under the 1933 Act if he "purchases unregistered securities from an issuer with a view to distribution."18

"Distribution" is not defined in the 1933 Act, but has traditionally been construed to be synonymous with the term "public offering" in Section $4(2) .{ }^{19}$ This reading of the two sections has permitted unregistered securities to be sold to the public through an intermediate private sale, if the purchaser in that private sale did not buy "with a view to" reselling the securities to the public.

To illustrate the scope of the exemption, consider a person who acquires securities through an unregistered private placement. A private resale of these restricted securities would be permitted under Section 4(1). Since the securities are not moving from the issuer to the public, the transaction is not a "distribution," i.e., public offering, and the seller, by definition, cannot be an underwriter. On the other hand, a public sale by a private placement purchaser might not be permitted under Section 4(1), for he may be acting as an underwriter if he purchased with a view to distribution or public resale. The broad purpose of the 1933 Act to require registration has meant that even a non-professional may be classified as an underwriter by the statute's terms.

Under the pre-Rule 144 practice, however, a person purchasing with a pure "investment intent" as opposed to a "view to distribution" has been free to change his mind and dispose of his unregistered holdings without thereby becoming an underwriter.20 This has com-

17. See note 16 supra.

18. The term "underwriter" means any person who has purchased from an issuer with a view to, or offers or sells for an issuer in connection with, the distribution of any security, or participates or has a direct or indirect participation in any stich undertaking, or participates or has a participation in the direct or indirect undertaking of such undertaking; but such term shall not include a person whose interest is limited to a commission from an underwriter or dealer not in excess of the usual and customary distributors' or sellers' commission. As used in this paragraph the term "issuer" shall include, in addition to an issuer, any person directy or indi. rectly controlling or controlled by the issuer, or any person under direct or indirece common control with the issuer.

1933 Act $\S 2(11)$.

19. See Gilligan, Will \& Co. v. SEC, 267 F.2d 461, 466.68 (2d Cir. 1959); Oklahoma Texas Trust, 2 S.E.C. 764,769 (1937), aff'd, 100 F.2d 888 (10h Cir. 1939); L. Loss, SECURITIEs Regulation 551 (temp. student ed. 1961); Orrick, Registralion Problems under the Federal Securities Act: Resales following Rule 133 and Exchange Transactions, 10 Hastings L.J. 1, 5 (1958). See p. 1575 supra.

20. See L. Loss, supra note 19, at $55 \mathrm{l}$. Recent illustrations are found in two SEC "no action" letters. Keene, Corp., [1971-1972 Transfer Binder] CCH FED. SEc. L. RE". 98,539 (restricted stock permitted to be sold for tax reasons). American All-Servus 
plicated the task of keeping the private placement private, for the availability of the Section 4(1) exemption for the resale of unregistered securities has been thereby made dependent on the intent of the purchaser at the time of the private placement.

Private placement purchasers seeking to demonstrate compliance with this standard invariably have delivered to the issuer a "letter of investment intent" representing and warranting that the securities are acquired without a view to distribution. ${ }^{21}$ Since this document is essentially self-serving it has been of little value. In the effort to discover the purchaser's original intent, the staff of the SEC has looked to a number of facts surrounding a proposed resale of restricted securities. ${ }^{22}$ Increasing reliance, however, has been placed on the length of time the securities have been held, ${ }^{23}$ perhaps on the theory that securities held for a long period of time were purchased for "investment" rather than "distribution." Although the SEC has stated that purchase of restricted securities with a view to public sale at any future date constitutes acquisition of securities with a view to distribution, ${ }^{24}$ it has been the common understanding of the bar that after a "reasonable holding period" restricted stock may be publicly sold without compliance with the registration requirements. ${ }^{25}$

Notwithstanding the weight given the holding period, pre-Rule 144 practice retained the possibility that the purchaser of a private placement would fail to qualify for a Section $4(1)$ exemption, and would thus be unable to resell the securities publicly. The possibility of being unable to sell the security was one good reason to investigate the issuer carefully before accepting the private placement. In addition, potential liability under the 1933 Act created a strong incentive for corporate issuers and transfer agents to police resales of restricted

Corp., [1970-1971 Transfer Binder] CCH FED. SEC. L. REP. T 78,086 (1971) (financial ruverses occurred; investment intent accepted). See also SEC Securities Act Relcasc No, 603 (Dec. 16, 1935); Comstock-Dexter Mines, Inc., 10 S.E.C. 358, 371 (1941).

21. See WheAT REPORT, supra note 3, at 163.

22. The factors considered are indicated in SEC Securities Act Release No. $455 \%$ (Nov. 6, 1962), and SEC Securities Act Release No. 285 (Jan. 24, 1935). Sec also Wise't REPORT, supra note 3 , at 162.74 .

23. See, e.g., Product Applications, Inc., [1970-1971 Transfer Binder] CCH Fev. SEC. L. REP. I 77,980 (1971); Digital Data Systems, Inc., [1970.1971 Transfer Binder] CGII FED. SEC. L. REP. 77 77,982 (1971). The Commission, despite its practice, has in its official pronouncements steadfastly rejected a definite holding period after which restricted securities may be publicly sold without registration. See, e.g., SEC Securities $\Lambda$ ct Relcase No. 4248 , at 6.7 (July 14,1960 ).

24. SEC Securities Act Release No. 4552, at 3-4 (Nov. 6, 1962).

25. Committee on Securities Regulation of the Bar of the City of New York, Conntunt Letter on Rule 144, at 21 (Oct. 14, 1971); see WHEst ReroRT, supra note 3, at 164.66; Schneider, Acquisitions under the Federal Securities Acts: A Program for Reform, 116 U. PA. L. REv. 1323, 1337 (1968); Throop, Federal Regulation of Securities Committec: Comments on the Wheat Report, 25 Bus. LAWYER 39, 46 (1969). 
securities. ${ }^{26}$ Nevertheless, the fact that private financing has remained economically attractive both to issuers and to purchasers is shown by the following statistic: In 1971, seventeen per cent of the gross proceeds of new corporate issues was raised privately. ${ }^{2 i}$

To understand the attractiveness of the private placement exemption to issuers of securities, it is necessary to know what is involved in the registration required for a public offering. Registration under the 1933 Act resembles an adversary process, with careful investigations being conducted by an independent underwriter, the underwriter's counsel, an independent accountant, and the staff of the SEC. ${ }^{28}$ This process is an expensive one, involving counsel fees, printing costs, SEC fees and underwriter's commissions. ${ }^{20}$ The total costs of registration may range from three per cent of the gross proceeds in a very large offering to nearly twenty per cent in a small one. ${ }^{30}$ Registration consumes time as well as money..$^{31}$ Months of delay are inherent in the process under the best of circumstances, ${ }^{32}$ and market conditions often cause underwriters to further postpone the offering. ${ }^{33}$ Besides these disadvantages, registration entails a thorough investigation of an issuer's condition and public disclosure of any adverse findings. A registered public offering will be anathema to any issuer which suspects that full disclosure of its affairs would impair its ability to sell its securities. ${ }^{34}$

26. A transfer agent may become a participant in a distribution of unregistered sccurities in violation of Section 5 and thus be subject to Section 12 liability. SEC v. Les Studs Corp., [1970-1971 Transfer Binder] CCH FED. SEc. L. REp. 93,087 (S.D.N.Y. 1971). For a discussion of some of the methods emplojed to inhibit marketability of restricted stock, see Israels, Stop Transfer Procedures and the Securities Act of 1933: Addendum to the Uniform Commercial Code-Arlicle 8,17 RutGers L. REv. 158 (1962). "Stop-transfer" procedures are discussed at Iength in SEC Securities Act Release No. 5121 (Dec. 30, 1970), and their importance is reaffirmed in SEC Securities Act Release No. 5223, at 15 (Jan. 11, 1972).

27. SEC, Statistical Bulletin 19 (March 1972). The ratio of gross proceeds of privately placed securities to new corporate issues fluctuates from year to year with changes in interest rates and the general market tone. In the speculative bull markets of 1963 , 1964, and 1965 the percentage of funds raised in private placements exceded fifty per cent. SEC, Statistical Bulletin 18 (March 1966). Despite the lower 1971 figure, there is a secular trend away from public flotation of securities. See Benston, The Effectiveness of the SEC's Accounting Disclosure Requirements, in ECONOMIC PouCY AxD TIE RECLlation of Corporate Securities 23, 67-72 (H. Manne ed. 1969).

28. The 1939 Act places heavy responsibility on underwriters and their counsel to exercise due diligence in making all material disclosures. See Complaint, SEC v. National Student Marketing Corp., Civil No. $225-72$ (S.D.N.Y., filed Feb. 3, 1972).

29. See, SEC, Cost of Flotation of Registered EQuiry Issues $1963-1965$ (March 1970 ).

30. Id. at 10-11.

31. See Epley, Letter Stock Restrictions and Registration Procedurc, in How to INVEST IN LETTER STOCK 7 (B. Makela ed. 1970).

32. WHEAT REPORT, supra note 3 , at 76.

33. See Hurwitz, The Broker's Role in Letler Stock, in How to INiEst IN LETtER Stock 23, 31 (B. Makela ed. 1970).

34. In fact private placements are particularly advantageous to issuers whoxe financial status falls short of standards met by most public offerings. 5 SEC, InstrrumoniL INvestor STUdy RePORT, H.R. DOc. No. 92-64, 92d Cong,, lst Sess. 2414-16 (1971) [hereinafter cited as INSTITUTIONAL INVESTOR STUDY REroRT]. 
In contrast to public offerings, private placements characteristically are informal, and the investigation conducted by purchasers is often cursory. ${ }^{35}$ The delay and expense of registration are avoided. Also avoided, should the issuer have something to hide, is the disclosure of corporate affairs. ${ }^{36}$

The principal advantage of private placements to the purchaser is the higher return that accompanies unregistered securitics. ${ }^{37}$ Onc study found that unregistered stock was privately placed at an average discount of twenty-three per cent from the market price. ${ }^{3 s}$ This increased return represents compensation for the encumbered status of the shares, the lower degree of disclosure, and part of the cost saving realized by lack of registration. ${ }^{30}$

In the case of debt securities, the return may be enhanced by several devices. One is an interest yield higher than the market return; another, sometimes termed an "equity kicker," may take the form of packaging stock options or bargain price stock with the debt issue. ${ }^{40}$ Gains to private placement purchasers in excess of 100 per cent are not uncommon. ${ }^{41}$

\section{Rule 144}

Rule $144^{42}$ enhances the relative attractiveness of private financing by reducing the uncertainty that previously attended the public re-

35. In Katz v. Amos Treat \& Co., 411 F.2d 10.46, 1050 (2d Cir. 1969) the private placement purchaser was given a tour of the plant of the corporate issuer and verbat assurances of a "tremendous backlog." In Value Line Fund, Inc. v. Matcus, [1961. 1966 Transfer Binder] CCH FED. SEC. L. REP. If 91,523 (S.D.N.Y. 1965), the privatc place. ment purchaser was a sophisticated professional investment advisory company. 'Ilic security analyst who studied the purchase, however, simply drew a few standard graphs on the price performance and carnings trend of the corporate issucr.

For a factual description of circumstances surrounding one private placement of threc million shares, see Jacobs v. Tenney, $316 \mathrm{~F}$. Supp. 151 (D. Del. 1970). See also Kaufman v. Diversified Indus., 40 U.S.L.W. 2818 (2d Cir. May 22, 1972); SEC Securities and Ex. change Act Release No. 9478 (Feb. 9, 1972).

36. If the issuer subsequently raises funds in an independent public offering, it must disclose all unregistered security sales within two years. 1933 Act Schedule $A$. For an example of the operation of this section see Hazel Bishop Inc., 10 S.E.C.718, 729 (1961). See generally Epley, supra note 31; Wall St. J., Nov. 18, 1969, at 1, col. 6.

37. A. Cohan, Yields on Corporate Debt Direcriy Placed 22 (1967); 5 Ins rilu hional INVESTOR Study ReporT, supra note 34, at 2414-16; Wall St. J., Nov. 18, 1969, at 1, col, 6. The higher rate of return on privately placed securities has prompted the formation of several mutual funds investing primarily in restricted securities. See, e.g., p'rospecrus of Federated Income and Private Placement Fund (1972). Se'e generally Hurwit, supro note 33 , at $23-24$.

38. 5 INSTITUTIONAL INVESTOR STUdY REIORT, supra note 34, at 2414-16.

39. Id.

40. See sources cited in note 37 supra.

41. See sources cited in note 37 supra.

42. 37 Fed. Reg. 596 (1962). See note 3 supra. 
sale of restricted securities. ${ }^{43}$ The rule provides that the purchaser of privately placed securities may publicly resell them in brokerage transactions if the following conditions are met: (1) the issuing company must either be current in filing its reports under the 1934 Securities and Exchange Act ${ }^{44}$ or, if not covered by that Act, ${ }^{45}$ there must be publicly available certain information about the company specified in the rule, ${ }^{46}$ (2) the prospective reseller must have been the full beneficial owner of the restricted securities for at least two years, ${ }^{4 \pi}$ (3) his sales of restricted securities, during any six-month period, must not exceed one per cent of the outstanding shares or other units of the class of the restricted holding. 18

The ultimate goal of Rule 144, as of all securities regulation, is the protection of the investing public. The same goal lay behind preRule 144 regulations of private placement resales. There has not been a change of goals, but a change of the means by which the continuing goal is to be attained. Previously, public protection seems to have rested heavily on the incentive for careful screening of securities by private placement purchasers created by the uncertainty inherent in the "intent" test. The uncertainty, and the motive it supposedly generated, naturally decreased as the length of the holding period became the primary factor assessed in permitting resale.

Rule 144 abandons any attempt to protect the public by fostering uncertainty among private purchasers. The purchaser knows before making the purchase that he will be able to resell publicly. Instead, the rule relies on the existence of specified objectively-measurable

43. See P. $15 \% 8$ supra.

44. The Securities and Exchange Act of 1934 is hercinafter referred to as the 1934 Act. Amendments to the annual periodic report, Form 10-K, 17 C.F.R. \$ 219.310 (1972), and the quarterly report, Form 10-0, 17 C.F.R. \$ $249.308 a$ (1972), under the 1934 Act, now require the registrant to include a statement that it has complied with the information requirements of Rule 144. 37 Fed. Reg. 600 (1972).

45. 15 U.S.C. $\$ \$ 78(1), 78(0)(d)(1970)$ indicate which companies must file periodic reports under the 1934 Act.

46. Rule $144(\mathrm{c})(2)$ refers to paragraph (a)(4) of Rule 15c2-11 under the $1934.1 \mathrm{ct}$, which requires disclosure of, among other things, the exact name of the issuer, the address of its principal executive offices, the exact title and class of the security, the number of shares or total amount of the security outstanding, the mature and extent of the issuer's facilities, the product or service offered, and financial information concerning the issuer including its most recent balance sheet and profit and loss statement, which shall be reasonably current. 17 C.F.R. \$ 240.15c2-11(a)(1) (1972). These itcms should be compared with the exhaustive 1933 Act disclosure required by Schedule $A$. 1933 Act Schedule A.

47. Rule 144(d).

48. Rule 144(e). If the securities are admitted to trading on a national exchange the limit is the lesser of (1) one per cent of the shares outstanding or (2) the average weekly reported volume of trading in such securities on all securities cxchanges during the four calendar weeks preceding the filing of Form 144, which gives notice of the proposed resale. 
conditions, which, if present, are regarded as providing the needed public protection. Underlying the Rule 144 requirements is the judg. ment that the unregistered public resale of privately placed securities does not present dangers to the public if (1) adequate information about the issuer is publicly available, ${ }^{40}$ (2) the private purchaser as* sumes the "full economic risks of investment" for a two-year period," and (3) the quantity sold does not disrupt the market. ${ }^{51}$ It will be argued below that these three conditions are not achieved by Rule 144.

\section{A. Adequacy of Information about the Issuer}

The test used in Rule 144 to establish the availability of adequate information about the issuer, for companies subject to the 1934 Act, is that the issuer be current in filing its required periodic reports with the SEG. ${ }^{52}$ Companies not subject to the 1934 Act, must make "publicly available" some (but not all) of the information contained in a 1934 Act periodic report. ${ }^{53}$

This test is deficient as to both the adequacy and availability of the information it generates. Useful comparison may be made with the information disclosed in a 1933 Act registration of a public offering. ${ }^{54}$

Periodic reports under the 1934 Act contain much less detail than the registration statements required for a public offering by the 1933 Act. ${ }^{55}$ One difference particularly worth noting is that a 1933 Act

49. SEC Securities Act Release No. 5223, at 7-8 (Jan. 11, 1972).

50. Id. at 8-10.

51. Id. at $10-11$.

52. Rule 144(c)(1).

53. Rule 144(c)(2). See note 46 supra.

54. This single comparison will not, of course, resolve the issue of the adequacy of the Rule 144 requirement, since the entire bundle of provisions contained in the rule, and not merely the information requirement, is the substitute for the protections accorded by 1933 Act registration. However, a proper evaluation of the rule as a whole requires an understanding of the disclosure gap existing between the rule and the 1938 Act. This comparison should not be understood as a criticism of 1934 Act periodic re. porting. Periodic reporting standards have been considerably upgraded to expose adverse financial developments with relative completeness and specd. Continuous disclosturc, however, of information as comprehensive as 1933 Act disclosure would be excessively costly. It is for this reason that the stricter standards of 1933 Act disclosure and liability are triggered only by a public offering. The comparison is justified because the cconomic effect of a Rule 144 sale is the same as that of a public offering. Both cases result in an infusion of public-market funds into the issuer's busincss.

55. The potential for misleading the public should not be underestimated even for major listed companies which report under the 1934 Act. In 1968, Omega Equities was a reporting company with its shares traded over the counter. Omega Equities, Docket No. 0-188, SEC, Directory of Companies Filing Annual Reports (196\%). Significant quitll. tities of its shares outstanding were unregistered, having been sold in private placenicnts. The company is now defunct. See Jacobs v. Tenney, 316 F. Supp. 151 (D. Del. 1970) In 1969, when Penn Central's financial situation was rapidly deteriorating, it caused the Pennsylvania Co., its wholly-owned investment subsidiary, to raise $\$ 35,000,000$ through 
registration statement discloses the use to be made of the funds raised by the sale. ${ }^{56}$ No such accounting is made in the 1934 Act report. ${ }^{57}$ Moreover, the 1934 Act report is produced by the reporting company alone, without the benefit of the multiple-party, adversary investigation of the company characteristic of a 1933 Act registration. ${ }^{58}$ As to companies not subject to the $1934 \mathrm{Act}$, the information requirements of the rule are even less stringent. ${ }^{50}$ Since these companies are small, often unseasoned enterprises, ${ }^{10}$ one may wonder why they are held to a standard of information lower than that applied to the larger, experienced companies which report under the 1934 Act. ${ }^{61}$

Nor is it clear why all reporting companies are treated the same. Conceivably, different quanta and kinds of information would be desirable from different kinds of reporting companies-major reporting companies, deficit ridden reporting companies, those involved in substantial litigation, and so on. ${ }^{02}$ The stark distinction between

a private placement. SEC, STAFf Study of the Financial Collapse of Pens Centmal Company, excerpt in [Current] CCH Fed. Sec. L. Rer. 78,931 at 82,011 (1972). The staff report further showed that the unwillingness of undenvriters and independent counsel (after scrutiny of company records) to endorse a public offering made it im. possible for Penn Central to offer its securities. Id. at 82,007. Without the purgative "housecleaning" effect of 1933 Act registration and the attendant publicity of a public offering, mismanagement may be insulated from public view for some time.

The staff of the SEC has in addition taken the position in recent "no action" letters that deficiencies in periodic reports or lack of an unqualified accountants' opinion will not nullify a 1934 Act filing for the purposes of Rule 144, except where the defieiencies are part of a plan to circumvent the public information requirements. Electronic Transistors Corp., [Current] CCH Fev. SEc. L. REr. I 78,974 (1972); Djnarad, Inc., [Current] CCH FED. SEC. L. REP. I 78,917 (1972).

56. See 1933 Act Schedule A and Item 3, Form S.1, 17 C.F.R. $\$ 239.11$ (1972).

57. See Form 10-K, 17 C.F.R. \$ 249.310 (1972); WHEAT RERoRT, supra notc 3, at 113.

58. Underwriters in a public offering are subject to a statutory duty to exercise due diligence in making full disclosure of material fact in a 1933 Act registration. 1933 Act $\$ 11(a)(4)$. See Complaint, SEC v. National Student Markcting Corp., Civil No. 205-72 (S.D.N.Y., filed Feb. 3, 1972).

59. See note 46 supra.

60. Registration and reporting under the 1934 Act is not required of issuers unless they are engaged in interstate commerce, have total assets exceeding $\$ 1,000,000$, and have outstanding a class of equity security held of record by 500 or more persons. 15 U.S.C. $\S 78(1)(\mathrm{g})(\mathrm{l})(1970)$.

61. The WhEAT REPORT concluded that, generally, favorable resale treatment should be given only to holders of restricted securities issued by reporting companies. WuEat REPORT, supra note 3 , at 206-10.

62. The distinctions suggested in the text are the basis of the qualifications for the use of registration on short forms. These rules make simplificd disclosure available to a limited number of reporting companies. For cxample, Form S.8, 17 C.F.R. $\$ 239.10($ (b) (1972), is limited to offerings to employees under qualified pension, profit sharing, or stock bonus plans. SEC Securities Act Release No. 3480 (June 16, 1953). Form S.9, 17 C.F.R. $\$ 239.22$ (1972), is limited to reporting companies selling high grade non-convertible debt securities. SEC Securities Act Release No. 3509 (July 21, 1934). Forms S.7, 17 C.F.R. \$ 239.26 (1972), and S-16, 17 C.F.R. \$ 239.27 (1972), are available only to reporting companies which have complied in all respects with the 1931 Act for the three years prior to filing. The issuer must also have had net income of at least $\$ 500,000$ for each of the five fiscal years preceding filing; and must not have defaulted on anj 
reporting companies on the one hand and non-reporting ones on the other is not completely responsive to the public's need for information.

The second weakness of the rule's information requirement concerns the "availability" of the information. Again by way of illustrative comparison, the 1933 Act requires that each prospective purchaser be supplied a prospectus. ${ }^{63}$ Rule 144, by contrast, does not require delivery of a prospectus to purchasers or even to members of a national exchange. ${ }^{64}$ Reports are simply filed with the SEC, ${ }^{00}$ under the standard of availability automatically set by the 1934 Act. No attempt is made to insure dissemination of the periodic reports to the investing public. Furthermore, the rule contains no standard by which to judge the public availability of the information required of non-reporting companies. ${ }^{66}$

\section{B. The Full Economic Risks of Investment}

The Commission argues that a two year holding period subjects purchasers in a private placement to the "full economic risks of investment." 67 Requiring the securities to be beneficially owned and fully paid for by the seller at least two years prior to resale, it is said, will prevent him from acting as a "conduit" for the sale of unregistered securities to the public. ${ }^{68}$ The underlying notion is that the risk of price decline during the mandatory holding period will encourage purchasers to buy wisely. Conceding for purposes of argument that a two year period of investment risk is long enough to generate vigilance among private placement purchasers, one may

interest payment, preferred stock dividend, sinking fund installment, or long terut lease rental payment within ten years. Moreover, a sale pursuant to Form S.16 must be effected on a national exchange and a prospectus must be delivered to all exchange members. SEC Securities Act Release No. 5100 (Dec. 16, 1970); SEC Sccurities $\Lambda$ ct Release No. 5117 (Dec. 23, 1970). For recent changes in the use of Forms S.7 and S.16, see SEC Securities Act Release No. 5265 (June 27, 1972).

The authors of the WHEAT REPORT appear to have considered the idea of distinguish. ing among reporting companies, but rejected it in the interest of simplicity. Wirst REPORT, supra note 3 , at 195.

63. 1933 Act $\S 5(\mathrm{~b})$.

64. Compare prospectus delivery requirements for Form S.16. See notc 62 stupra.

65. Financial analysts have long complained about the inadequate dissemination of 1934 Act periodic reports. See, e.g., Carlson, Corporate Information and Disclosture, 28 Financial ANalysts J. 94 (1972).

66. The staff of the SEC has indicated in an unpublished "no action" letter that guidelines concerning the availability of public information are to be announced in an interpretative release. George D.B. Bonbright \& Co., summary reproduced in BNA SEC. REG. \& L. REP. No. 167 at C-2 (1972).

67. SEC Securities Act Release No. 5223, at 6, 8 (Jan. 11, 1972).

68. Id. One reason the one year holding period suggested in the WuEst RErokt was rejected was that it "would result in sale of large amounts of unregistercd securitics to the public." SEC Securities Act Release No. 5087, at 3 (Sept. 22, 1970). 
still wonder whether the rule actually subjects purchasers to the "full economic risks of investment" during this period.

In order to prevent a private placement purchaser from hedging his investment risk, a provision was added to the final draft of Rule 144 suspending the computation of the holding period whenever the holder has a "short position" in, or holds an option to sell, units of the same class or units convertible into the same class as the restricted security. ${ }^{69}$ Innovative as this provision is, it nonetheless permits substantial hedging. The private placement purchaser can reduce investment risk not only by using short sales and options to scll, but also by taking advantage of the effect of Rule 144's abolition of the "fungibility doctrine" 70 and its treatment of convertible securities, 71 and by selling restricted stock through affiliates. ${ }^{72}$

Short Sales and Acquisitions of Puts. A short sale is simply the sale of a borrowed security, ${ }^{73}$ and a put is an option to sell a share at a specified price during a specified period.it By selling short or acquiring a put in the quantity of a security held, the holder is completely insulated against loss. Any loss resulting from a price decline is exactly matched by the gain generated by the put or short sale. Of course, the converse is true, so the holder in such a case would lose any profit from a price increase. The holder of a restricted security, however, may be willing to avoid both gain and loss during the two years, and on resale would make his profit from the discount he received when he purchased the security.

One weakness of the short sale provision in Rule 144 is that its application is limited to certain kinds of stock-stock of the same

69. Rule 144(d)(3).

70. See p. 1587 infra.

71. See pp. 1587-89 infra.

72. See pp. 1589-90 infra.

73. In a short sale the security is usually borrowed from the broker executing the transaction. Large brokerage houses maintain inventorics of different securities that are deposited with them by their customers for safekeeping. If a brokerage house does not have a particular security in its inventory it often will borrow the security from another brokerage house for the customer who wishes to make the short salc. The profit on a short sale is made when the price of the stock gous down. The seller can then repurchase at a lower price and return the share he borrowed. This operation is often called "covering a short position." See the lucid explanation of short sales in P. Susturusox, Ecovomics 401 (8th ed. 1970).

74. The profit on a put, like that on a successful short sale, is made if the price of the security goes down. A put entitles the holder to sell a security at a certain price (the striking price) within a certain period of time. If the price of the security falls, the optionee may buy the security at the market price and exercise his put to sell at the striking price. The difference between the striking price and the market price less the cost of the option and brokerage commissions will be his profit. See $R$. Bavcen, $H$. Torgerson \& H. Guthmans, Investalent Principles and Practices 76 (6th cd. 1969) [hereinafter cited as. INvestaient Principles]. 
class or stock which is convertible into securities of the same class as the restricted holding. ${ }^{75}$ All equity securities reflect the underlying value of the issuing company, ${ }^{76}$ and price changes for equity securities of the same issuer are highly correlated. ${ }^{77}$ Thus a holder of restricted equity securities may protect his position by shorting a share which is neither the equivalent of, nor convertible into, securities of the same class as his restricted holding. ${ }^{78}$

Furthermore, the rule fails to recognize that the prices of all sccurities are interrelated, and that the risk of a portfolio may be substantially lower than the risk of a particular security. ${ }^{70}$ Even if sccurities of the same issuer not convertible into the restricted class are unavailable, Rule 144 will not prevent minimization of investment risk through short sales and acquisition of puts of other securities. Especially high degrees of correlation may be expected in the price fluctuations of securities of companies in the same industry or of companies producing complementary products. ${ }^{80}$ So long as there is any positive correlation, i.e., the prices of the two securitics move in the same direction, ${ }^{81}$ it is possible to minimize the overall risk of a portfolio by acquiring a put on, or by selling short, the correlated stock.82 For example, selling short securities of battery, tirc, or spark plug manufacturing companies will minimize the risk in-

75. Rule 144(d)(3)(i). The running of the holding period on restricted debt securities is suspended upon the short sale or acquisition of a put on any debt security of the issuer, regardless of convertibility into the restricted class. Rule 144(d)(3)(ii).

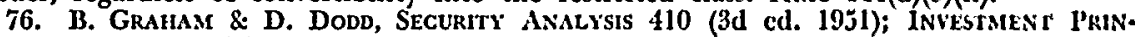
CIPLES, supra note 74 , at 216.34 .

77. The general principle of hedging is described in B. Gesinsu \& D. Dovv, supra note 76, at 545. More explicit strategies may be found in $\mathrm{E}$. 'THOkt' \& S. KAssour, BrAT THE MARKeT (1967).

78. To illustrate this principle assume an issuer has outstanding two classes of common stock, which differ perhaps only in voting rights and which are not convertible into shares of each class. Assume restricted shares of the first class arc held by private placement purchasers. An option to sell the shares of the second class will protect thic purchaser from price decline during the two-year period without suspending the runnings of the computation of the length of time the securities have becn held. $A$ short salu accomplishes the same result. The prices of the two securitics can be expected to move together. The loss on the restricted stock will be offset by the short salc profit. After two years the position may be liquidated and the restricted holdings sold publicly via Rule 144.

79. See generally, H. Markowitz, Portfolio Selection: EFfCient Divensification OF INVESTMENTS (1959).

80. Id. at 32. The statistical correlation among nine listed stocks is calculated in a numerical example. Id. at 113. See also, F. ReNwick, INTRodUction To INVESTAENTS ANI Finance: Theory and Analysis 448 (1971).

81. If prices are negatively correlated, no short sales are necessary to minimize in. vestment risk. For example, purchasing securities of the proverbial ice and coal companies, Samuelson, General Proof that Diversification Pays, 25 J. OF Fin. AND QUANr. ANALYsis $1,7.8$ (1967), or in "war" and "peace" companies, Cohen, The Suitability Rule and Economic Theory, 80 YaLE L.J. 1604, 1611-14 (1970), would minimizc portfolio risk. 82. See F. RENwICk, supra note 80 , at 163-61, $426-35$. 
volved in holding restricted securities of an automobile manufacturing company. Similar or superior protection might be gained by shorting shares of another automobile manufacturer.

The Fungibility Doctrine. Rule 144 abolishes the "fungibility doctrine."83 Under that doctrine, securities acquired on the open market, while the private placement purchaser held restricted holdings of the same class, also became restricted as to resale. The underlying rationale of the fungibility doctrine was that it is inconsistent for a private placement purchaser to make an investment representation with respect to some shares and simultaneously to sell publicly other shares representing fungible economic interests. ${ }^{84}$

A subtle economic aspect of the fungibility doctrine was the imposition of added investment risk on the purchaser of privately placed securities. The fungibility doctrine subjected the holder of restricted securities to illiquidity in later-acquired securities of the same class as those privately placed and hence created a strong incentive to fully investigate the affairs of the corporate issuer. Rule 144 removes this incentive by assuring those who acquire restricted securities in unregistered transactions of the complete liquidity of later-acquired securities.

Convertible Securities. A "convertible" is a senior security (debt or preferred stock) which may be exchanged at the option of the holder for common stock. ${ }^{85}$ This senior security typically entitles the holder to priorities in liquidation or bankruptcy. The higher yield on preferred stock or debt, as well as the possibility of redemption by the corporate issuer, will reduce the magnitude of market price fluctua-

83. SEC Securities Act Release No. 5223, at 9 (Jan. 11, 1972). Kleinbard, Bell \& Brecker, [1971-1972 Transfer Binder] CCH FED. SEc. L. REr. 78,717 (1972).

The Commission had carlier concluded that a holding period vould be of litule effect without a fungibility rule of some kind to prevent "rolling distribution." W'ieat REPORT, supra note 3, at 201-02. Accordingly, all carly versions of the rule preserved 2 limited fungibility doctrine. Proposed Rule 144(d)(2), SEC Securities Act Relense No. 4186 (Sept. 10, 1971); Proposed Rule 144(a)(1)(iii), SEC Securitics Act Release No. 5087 (Sept. 22, 1970); Proposed Rule 162(c)(1), SEC Securities Act Release No. 4997 (Sept. 4, 1969). For a pre-Rule 144 "no action" letter upholding fungibility, see Computcr Automation, Inc., [Current] CCH FED. SEC. L. REP. T 78,848 (1972).

84. The doctrine was first enunciated and explained in two SEC decisions. Skiatron Electronics and Television Corp., 40 S.E.C. 236 (1960), Lewissohn Copper Corp., 38 S.E.C. 226 (1958). Even those critical of the fungibility rule recognize a need for some degree of limitation on the intermixture of purchases and sales of restricted stock. See, e.5., Samet, The Concept of Fungibility in the Securities Law', 27 Bus. Lavres 383 (1972).

85. In "no action" letters, the staff of the SEC has taken the position that a note which may be exchanged for common stock only when accompanied by the viarrant issued with the note is not a "convertible security" under Rule $144(\mathrm{~d})(\mathrm{A})(\mathrm{B})$. Wright Airlines, Inc., [Current] CCH FED. SEC. L. REP. 978,937 (1972); Microlorm Data Systcms, Inc., [Current] CCH FED. SEC. L. REP. \$ 78,916 (1972). Thus, the term "convertible securities" only embraces securities which may be exchanged for other securities without any other consideration. 
tions. ${ }^{86}$ A senior security which is convertible into common stock also assures the holder of participation in the price appreciation of the underlying common stock.

The computation of the holding period for restricted convertible securities under Rule $144^{87}$ creates what may well become the primary means of avoiding full economic risk of investment during the two year holding period. Prior to Rule 144, privately placed convertible securities were governed by Rule $155 .^{88}$ Under that rule any public resale of a restricted convertible violated the 1933 Act, regardless of investment intent or length of the holding period. ${ }^{80}$ The holding period of common stock acquired through conversion of securities related back to the date of conversion. By contrast, Rule 144 views the convertible security as a "package" of two securities. Conversion docs not start the holding period running anew, and the holding period of the underlying common stock relates back to the acquisition of the convertible, regardless of when the conversion was effected. ${ }^{00}$ It is easy to see that Rule 155 imposed far more economic risk than Rule 144. Under Rule 155 convertible securities did not minimize risk, for distribution of the convertible was forbidden without registration. ${ }^{01}$ If an unregistered public sale was desired, it was necessary to exercise the conversion option and hold the more risky common stock long enough to satisfy the SEC. Rule 144 makes it possible to bear the limited risk of a preferred issue during the two year holding period, and then either exercise the conversion option and receive the market price of the more risky underlying issue, or sell the convertible itself, at a price reflecting the value of the underlying common stock. One of

86. Investment Principles, supra note 74, at 235; B. Grahnm \& D. Dodo, supra note 76 , at 521-29.

The magnitude of price fluctuations is considered by economists to correspond to the "riskiness" of an investment in a particular asset. See generally H. Makkowliz, supra note 79.

87. Rule 144(d)(4)(B).

88. 17 C.F.R. $\$ 230.155$ (1972). Rule 144 rescinds Rule 155. 37 Fed. Reg. 596 (1972).

89. The Commission's rationale for requiring registration of all sales of restricted convertible securities involves the following logical chain: (1) The private placement of a security which is immediately convertible into another is an offer by the isstter of two securities, with the offer of the underlying security continuing until the convertible right is exercised or expires; (2) The corporate issuer has a direct, intimate and conl. tinuing connection with this offer of the underlying security; (3) $A$ public sale of the convertible by the private placement purchaser would be a transaction involving the issuer in a public offering of the underlying unregistered security in violation of the 1933 Act. See SEC Securities Act Release No. 4162 (Dec. 2, 1959), SEC Securities Act Release No. 4248 (July 14, 1960) (explaining Proposed Rule 155), and SEG Secturities Act Release No. 4450 (Feb. 7, 1962). For a commentator's elaboration of this rationale, see Gadsby, Private Placement of Convertible Securities, 15 Bus. LAWYER 470 (1960).

90. Rule 144(d)(4)(B).

91. See, e.g., Emmanuel Deetjen \& Co., [1970-1971 Transfer Binder] CCH FEv. SEc. L. REP. I 78,200 (1971). 
the principal features of private placements, as opposed to public financing, is the ability of the issuer to tailor the characteristics of the securities to the needs of the private purchaser. ${ }^{92}$ This makes it likely that negotiation between issuers and prospective private placement purchasers will lead to widespread use of convertible securities as a means of avoiding investment risk. ${ }^{23}$

Sales by Affiliates. Pre-Rule 144 law recognized the community of interest between a corporate issuer and a person controlling or controlled by the issuer. Thus, a sale of unregistered stock by such a person was held the equivalent of a transaction by the issuer. ${ }^{04}$ Under Rule 144, however, the affiliate of an issuer is recognized as a person distinct from the corporate issuer, free to engage in Rule 144 transactions. The definition of an affiliate is "a person that directly, or indirectly through one or more intermediaries, controls, or is controlled by, or is under common control with, such issuer." ${ }^{25}$ The literal language of Rule 144 would permit circumvention of the 1933 Act registration requirements by the use of subsidiaries. The issuing corporation could transfer its shares to a subsidiary under a Section 4(2) claim of private financing. The subsidiary, after the two year holding period, would be able to sell the restricted securities in Rule 144 transactions. Of course, there would be no real "investment risk" borne by the subsidiary, since its identity is merged with that of the issuer. The proceeds of the Rule 144 sale could ultimately be passed to the parent or sister corporation by means of a loan, capital contribution, or dividend. While such blatant exploitation of Rule 144 may not succeed, less dramatic abuses are a realistic possibility. A case in point is the position taken by the SEC staff that a controlled pension trust may be an "affiliate" of the issuer under Rule 144 and may sell securities of the parent in Rule 144 transactions. $^{.0}$

The treatment of affiliates is an area in which the fundamental premises of Rule 144, and not merely its mechanics, are highly questionable. Even if some degree of investment risk is imposed on affiliates when

92. Epley, supra note 31, at 12; 5 INstrTutional INvestor Studr RErort, supra note 34 , at 2414 .

93. Additional discussion of the increased attractiveness of convertible debt can be found in Rice, Potential Effects of Pending Securities and Exchange Rules on Privale Financing and Business Acquisitions, 23 SrAv. L. REv. 287, 298 (1971).

91. The last clause of the definition of "underwriter" provides:

As used in this paragraph, the term "issuer" shall include, in addition to an

issuer, any person directly or indirectly controlling or controlled by the issuer, or

any person under direct or indirect common conirol with the issuer.

1933 Act $\$ 2(11)$. See generally L. Loss, supra note 19, at 782.

95. Rule 144(a)(1).

96. Winkleman Stores, [1971-1972 Transfer Binder] CCH FED. SEc. L. REP. 978,771 (1972). 
they purchase restricted securities from parent or sister entities, it is far from clear that such risk will have the cautionary effect in purchase decisions that it would have on an unaffiliated purchaser. Purchases of an affiliate's securities are influenced by considerations other than rational investment behavior, considerations which are capable of overruling decisions that the risk factor might otherwise compel. As a result, the protection provided the public by Rule 144 is signilicantly weakened when a private placement purchaser is affiliated with the issuer of the securities.

\section{Quantity Limits}

Under Rule 144 the quantity of restricted securities which a person may sell within any six month period is restricted to the lesser of (1) one per cent of the shares or other units of the class outstanding or (2) the average weekly volume of trading in the security on all cxchanges during the prior four calendar weeks. ${ }^{07}$ This quantity limit is designed to minimize the impact of sales of restricted securities on the trading markets. It incidentally subjects the private placement purchaser to a degree of illiquidity should he purchase a quantity too large to be sold in a single six month period.

The limit imposed by Rule 144 does not achieve its goal of market protection. It applies only to the individual holder of unregistered securities and contains no overall provision to prevent market disruption caused by the aggregate effect of permissible individual transactions. ${ }^{98}$ Thus, if each of twenty-five institutions privately holds one

97. Rule 144(e). If the security is not listed on an exchange the one per cent limit applies.

In computing the quantity limits for affiliates, sales of restricted sccurities and "other" securities are counted together. Rule 144(e)(1). This resembles a limited "fungibility" provision for affiliates only. See also p. 1587 supra.

Rule 144 limits may be contrasted with those of Rule 237, promulgated with Rule 144. 37 Fed. Reg. 590 (1972). Under Rule 237 any person not an issuer, affiliate of the issuer, or a broker or dealer may sell unregistered securities in negotiated transactions if the securities have been held for five years and the issuer is a doncstic organization actively engaged in business as a going concern for at least the last five ycars. Thicse sales, however, are limited to one per cent of the class outstanding or $\$ 50,000$, whichever is less, in any twelve month period. In addition, the amount that may be sold under the rule is reduced by sales made pursuant to an excmption under Regulation $\Lambda$, sec text infra, and under Rule 144 during the period.

98. Sales of restricted stock by pledgees and pledgors, donecs and donors, trusts and the settlors of such trusts, estates and beneficiaries of such estates, and persons acting in concert are aggregated in certain cases in computing the Rule 144 quantity limit. Rule 144(e)(3) (i)-(vi). Under pre-Rule 144 law the existence of a large number of sales of restricted securities by unrelated persons was relevant to a determination of whether there had been an illegal distribution even if the persons had not acted in concert. Sic', e.g., Viatron Computer Systems Corp., [1970-1971 Transfer Binder] CCH FED. SEc. L. REP. T 78,052 (1971), Unicapital Corp., [1970-1971 Transfer Binder] CCH FEd. SEC. L. REN. If 78,123 (1971). 
per cent of the shares of the class outstanding, they may collectively sell as much as twenty-five per cent of the outstanding shares within a six month period.

The Rule 144 quantity limit should be contrasted with that of Regulation A.99 Often called the small offering exemption, this regulation permits an issuer publicly to sell up to $\$ 500,000$ of securities per year without registration under the $1933 \mathrm{Act}$. This total includes the amount by which aggregate sales by non-controlling persons exceed $\$ 300,000$. Rule 144 clearly permits unregistered securities to enter the public market in greater volume than would qualify as a small offering.

Rule 144 also permits sales up to the quantity limit within successive six month periods. ${ }^{100}$ Thus up to one per cent of the class outstanding or the average four week trading volume may be sold every six months. This should be contrasted with Rule 154, which formerly governed certain sales by controlling stockholders. ${ }^{101}$ Under that rule sales within successive six month periods were deemed so "substantial" as to be an illegal distribution. ${ }^{102}$

\section{Conclusion}

No regulatory approach to the problems in this area could be perfectly prophylactic, but Rule 144 seems particularly porous. Happily, the SEC states that the rule is experimental and that it will be rescinded or amended if experience proves that it is not operating for the protection of the public. ${ }^{103}$ The defects that have been discussed deserve the Commission's prompt attention and corrective action.

99. 17 C.F.R. $\$ \$ 230.251-262$ (1972).

100. SEC Securities Act Release No. 5223, at 11 (Jan. 11, 1972). Jacols, Persinger \& Parker, [Current] CCH FED. SEC. L. REP. T 78,945 (1972).

101. Rule 154 contained a definition of the term "distribution" which was used in determining the availability of an exemption for a brokerage transaction under $\$ 4(4)$ of the 1933 Act. 17 C.F.R. $\$ 230.154$ (1972). Rule 154 was rescinded by Rule 144.37 Fed. Reg. 596 (1972). Distributions generally were held not to include "traneactions involving an amount not substantial in relation to the number of shares or units of the security outstanding and the aggregate volume of trading in such security." SEC Securities Act Release No. 4818 (Jan. 21, 1966).

102. SEC Securities Act Release No. 4818 (Jan. 21, 1960); Computer Sciences Corp., [1970-1971 Transfer Binder] CCH FED. SEC. L. REp. 78,175 (1971).

SEC Securities Act Release No. 5223 warns that technical compliance with the letter of Rule 144 will not assure an exemption if the Rule 141 sales are part of a plan to distribute securities to the public. SEC Securities Act Release No. 5223, at 13 (Jan. 11, 1972). This cryptic sentence does not revive the "intent to distribute" standard. Jacobs, Persinger \& Parker, [Current] CCH FEd. SEC. L. REr. 78,945 (1972). At anj ratc, once objective standards defining distribution are set out, it may be extremely difficult to halt an allegedly "illegal plan of distribution" which technically complics with the rule. Cf. SEC v. Arco Industries, Inc., [1970-1971 Transfer Binder] CCH FED. SEc. L. REP. I 92,921 (S.D.N.Y., Jan. 18, 1971).

103. SEC Securities Act Release No. 5223, at 13 (Jan. 11, 1972). 